\title{
Silver nanoparticles incorporated into nanostructured biopolymer membranes produced by electrospinning: a study of antimicrobial activity
}

\author{
Karen Segala $^{1, *}$, Silvia Vaz Guerra Nista ${ }^{1}$, Lívia Cordi ${ }^{2,3}$, Maria Trindade Marques Bizarria ${ }^{1}$, José \\ de Ávila Júnior ${ }^{4}$, Sirlene Adriana Kleinubing ${ }^{1}$, Deborah Cristina Cruz ${ }^{1}$, Marcelo Brocchi², Liliane \\ Maria Ferrareso Lona ${ }^{1}$, Nelson Eduardo Durán Caballero ${ }^{3,5,6}$, Lucia Helena Innocentini Mei ${ }^{1}$
}

${ }^{1}$ Department of Materials Engineering and Bioprocess, School of Chemical Engineering, University of Campinas, UNICAMP, Campinas, SP, Brazil, ${ }^{2}$ Department of Genetics, Evolution and Bioagents, Institute of Biology, University of Campinas, UNICAMP, Campinas, SP, Brazil, ${ }^{3}$ Chemistry Institute, University of Campinas, UNICAMP, Campinas, SP, Brazil, ${ }^{4}$ Mechanical Engineering Department, Federal University of São João del-Rey, São João del-Rei, MG, Brazil, ${ }^{5}$ NanoBioss, Institute of Chemistry, UNICAMP, Campinas, SP, Brazil, ${ }^{6}$ Brazilian Network on Nanotoxicology, MCTI/CNPq, Institute of Chemistry, UNICAMP, SP, Brazil

\begin{abstract}
This study examines the antimicrobial activity of silver nanoparticles incorporated into nanostructured membranes made of cellulose acetate (CA) and blends of chitosan/poly-(ethylene oxide, CTS/PEO) and prepared by electrospinning. The formation of chemically synthesized Ag nanoparticles (AgNPs) was monitore by UV-visible spectroscopy (UV-Vis) and characterized by transmission electron microscopy (TEM). The size distribution of the AgNPs was measured by dynamic light scattering (DLS), with an average size of approximately $20 \mathrm{~nm}$. The presence of AgNPs on the surface of electrospun nanofibers was observed by field emission electron microscopy (FEG) and confirmed by TEM. The antimicrobial activity of AgNPs incorporated into nanostructured membranes made of CA and CTS/PEO electrospun nanofibers was evaluated in the presence of both Gram-positive bacteria, such as Staphylococcus aureus ATCC 29213 and Propionibacterium acnes ATCC 6919, and Gram-negative bacteria, such as Escherichia coli ATCC 25992 and Pseudomonas aeruginosa ATCC 17933. Microbiological results showed that the presence of AgNPs in CA and CTS/PEO nanostructured membranes has significant antimicrobial activity for the Gram-positive bacteria Escherichia coli and Propionibacterium acnes.
\end{abstract}

Uniterms: Electrospinning. Silver nanoparticles/antibacterial activity. Cellulose acetate. Chitosan.

\begin{abstract}
Neste trabalho avaliou-se a atividade antimicrobiana das nanopartículas de prata (AgNPs) incorporadas em membranas de acetato celulose (AC) e blendas de quitosana/poli-óxido de etileno (CTS/PEO) preparadas pelo método de eletrofiação. A formação das AgNPs previamente sintetizadas foi monitorada por UV-Vis e caracterizada por microscopia eletrônica de transmissão (MET). A distribuição de tamanho das AgNPs foi mensurada por espalhamento de luz dinâmico, com tamanho médio em torno de $20 \mathrm{~nm}$. A presença das NPs na superfície das nanofibras eletrofiadas foi observada por microscopia eletrônica com emissão de campo (FEG) e confirmada por MET. A atividade antimicrobiana das membranas nanoestruturadas de AC e CTS/PEO foi avaliada pelo uso de bactérias Gram-positivas, tais como Staphylococcus aureus ATCC 29213 e Propionibacterium acnes ATCC 6919, e Gram-negativas, como Escherichia coli ATCC 25992 e Pseudomonas aeruginosa ATCC 17933. Os resultados microbiológicos mostraram a presença das AgNPs nas membranas de AC e CTS/PEO com significativa atividade antimicrobiana para Escherichia coli e Propionibacterium acnes, respectivamente.
\end{abstract}

Unitermos: Eletrofiação. Nanopartículas de prata/atividade antimicrobiana. Acetato de celulose. Quitosana.

\footnotetext{
*Correspondence: K. Segala. Departamento de Engenharia de Materiais e Bioprocessos. Faculdade de Engenharia Química. Universidade Estadual de Campinas. Avenida Albert Einstein, 500, 13083-970 - Campinas - SP, Brazil. E-mail:ksegala@uol.com.br
} 


\section{INTRODUCTION}

The use of metal nanoparticles in various medical and biotechnological applications is one of the most investigated areas in materials science. These applications require appropriate chemical functionalization of the nanoparticles with organic molecules or their incorporation into polymer matrices (Dallas, Sharma, Zboril, 2011). Among the numerous types of nanoparticles that have been used to decorate polymers, silver nanoparticles (AgNPs) are the most researched, due to their electronic properties (Líu et al., 2010; Tricoli, Pratsinis, 2009; Chen et al., 2010), and optical (Zeng et al., 2007), catalytic (Severin et al., 2007; Signori et al., 2010) and antimicrobial activities (Panacek et al., 2006; Kvitek et al., 2008; Prema, Raju, 2009; Chaloupka, Malam, Seifalian, 2010).

Recently, there has been increasing interest in studying nanostructured biopolymers with antimicrobial characteristics for their immense potential use in devices that require a high antiseptic character. Recent studies have shown that an especially lucrative opportunity lies in applying these polymeric nanostructures in the medical field (Abdelgawada, Hudsona, Rojas, 2014; Chaloupka, Malam, Seifalian, 2010; Dallas, Sharma, Zboril, 2011). The literature contains a great deal of studies demonstrating the successful application of these nanostructures in the healthcare, pharmaceutical and cosmetic industries for repairing and regenerating the skin and organs; as drug delivery vectors and therapies; biocompatible and biodegradable implants; in medical diagnosis and instrumentation; as tissue protective agents that guard against infection; and in cosmetics, molecular medicines, supplements and body care applications in the field of dentistry (Nista, Bettini; Mei, 2015; Bizarria, Davila, Mei, 2014; Kleinubing et al., 2014).

The AgNPs possess superior antimicrobial properties compared to other salts, due to their extremely large surface area, which provides better contact with microorganisms (Rai, Yadav, Gade 2009). Although the mechanism of action of silver nanoparticles on microorganisms is not fully understood, there are hypotheses that these nanoparticles can cause cell lysis or inhibit cell transduction (Prabhu, Poulose, 2012).

Studies are being carried out to determine how to incorporate AgNPs into biopolymeric membranes (Ellison et al., 2014; Kanmani, Rhim, 2014; Rhim, Wang, Hong, 2013), due to the biocompatibility of these polymers (Okamoto, John, 2013) with multiple biological systems and their enhanced antimicrobial activity (Guo et al., 2013; Madhumathi et al., 2010). Materials based on cellulose like CA are a particularly good choice for preparing these films, due to their excellent performance characteristics; CA, for example, exhibits good toughness, high biocompatibility and relatively low cost (Han et al., 2013; Abou-Zeida et al., 2011; Ferjani et al., 2002).

Polymeric blends have received considerable attention from researchers in recent decades as a means to improve the physico-chemical and mechanical properties of materials (Abou-Zeida et al., 2011). Polymeric films made from the blends of CTS/PEO show better thermal, chemical, mechanical and conductive properties than do films of pure chitosan (CTS) or PEO, and moreover acquire additional functionalities due to specific interactions between the amino groups of chitosan and ether group of PEO (Zivanovic, Davidson, Kit, 2007; Alexeev et al., 2000).

Hybrid nanomaterials have been developed for antimicrobial applications. Recent studies of nanofiber mat wound dressings made from multicomponent (chitosan/ silver-NPs/polyvinyl alcohol) systems showed synergistic antibacterial effects achieved by combining chitosan with Ag-NPs (Abdelgawada, Hudsona, Rojas, 2014).

Many techniques have been employed to prepare nanofibers from polymers (Soyekwo et al., 2014). Electrospinning is a technology that has been widely used as a new method for the production of fibers on the nanometer scale. The produced fibers have a high surface area to volume ratio and generate highly porous fibrilic films exhibiting excellent mechanical properties in comparison to other materials with the same scale. In the last decade, this preparation method has achieved prominence for its use in the production of biocompatible and biodegradable polymers (Khan, 2012).

Electrospun nanofibers of karaya gum were blended with PVA to produce uniform nanofibers (PVA/ GK). Silver nanoparticles (Ag-NPs) were synthesized by chemically reducing $\mathrm{AgNO}_{3}$ with the PVA/GK solution, the GK hydroxyl groups being oxidized to carbonyl groups, and the $\mathrm{Ag}+$ cations being reduced to metallic AgNPs. These PVA/GK/Ag solutions were then electrospun to produce nanofiber membranes containing AgNPs (Ag-MEMs). The authors showed that the polymeric solution (PVA/GK/Ag) and the final AgNP-containing membrane (Ag-MEM) exhibited clear antibacterial activity toward Gram-negative E. coli and P. aeruginosa and Gram-positive $S$. aureus. These newly synthesized nanomaterials show great potential for the development of environmentally friendly antibacterial devices for medical, food packaging, and water purification purposes (Padil et al., 2015).

In recent years, our research group has been dedicated to the study of nanostructured biopolymer 
membranes for application in the medical and dental fields (Nista et al., 2012; Nista et al., 2013; Nista, Bettini, Mei, 2015; Bizarria, Davila, Mei, 2014; Kleinubing et al., 2014).

This work focuses on the synthesis, characterization, and comparative antimicrobial activities of AgNPs incorporated into nanostructured biopolymer membranes made from either a blend of CTS/PEO or CA when tested against both Gram-positive and Gram-negative bacteria.

\section{MATERIAL AND METHODS}

\section{Material}

All chemical reagents were of analytical grade and used without further purification. White cellulose acetate powder $(\mathrm{Mr}=29,000$; degree of substitution $=40 \%)$; CTS obtained from crushed shells (middle-viscosity); PEO and silver nitrate $\left(\mathrm{AgNO}_{3}, 99.0 \%\right)$ were purchased from Sigma-Aldrich Co. Acetone and $N, N$-dimethyl acetamide (DMAc) were supplied by Synth and Merck, respectively. Ultra-pure water was used to synthesize the AgNPs, and distilled water was used for the other syntheses.

\section{Synthesis of AgNPs}

AgNPs were synthesized in aqueous media by the chemical reduction of $\mathrm{AgNO}_{3}$, using $\mathrm{NaBH}_{4}$ as a reducing agent and sodium citrate as stabilizer (Dutra et al., 2008). An equimolar solution of $\mathrm{AgNO}_{3}$ and sodium citrate was maintained at approximately $4{ }^{\circ} \mathrm{C}$ under vigorous stirring for 30 minutes, while $0.01 \mathrm{~mol} \mathrm{~L}^{-1}$ of $\mathrm{NaBH}_{4}$ was added dropwise. After that, the solution acquired a yellow turbid aspect, signaling that a colloidal Ag suspension had formed (Jana, Gearhearta, Murphy, 2001; Murphy, Jana 2002; Solomon et al., 2007).

\section{UV-Vis spectra and DLS}

The formation of the nano-sized AgNPs was monitored by measuring the UV-Vis spectrum (Hitachi U-200) at approximately $400 \mathrm{~nm}$ (Solomon et al., 2007) and the size distribution was measured by DLS using a Malvern Zetasizer Nano series compact scattering spectrometer.

\section{TEM analyses}

The morphology of the AgNPs was observed by transmission electron microscopy (HR-TEM), using a JEOL JEM 3010 operating at $300 \mathrm{kV}$.

\section{Preparation of CTS/PEO blends}

Polymeric blends were prepared by mixing CTS and PEO solutions in the absence and presence of AgNPs. In a flask, $10 \mathrm{~mL}$ of CTS to $6 \%(\mathrm{w} / \mathrm{w})$ was added, together with $10 \mathrm{~mL}$ of PEO at a concentration of $3 \%(\mathrm{w} / \mathrm{v})$. This blend was stirred continually for approximately 2 hours to ensure complete homogenization. After this, approximately 10 $\mathrm{mL}$ of AgNPs-containing aqueous solution was added to the blend.

\section{Electrospinning of CTS/PEO solutions}

The electrospinning technique is based on electrostatic forces. Generally, the polymeric solution is maintained by its surface tension in the form of a drop at the end of a capillary metal. High voltage is applied to create an electric field between the capillary and the fiber collector, usually a grounded metal plate or a grounded rotating device (Figure 1).

Nanostructured membranes of CTS/PEO with and without AgNPs were made by the electrospinning technique, according to the methodology described by Vulcani et al. (2012). The resulting blend of CTS/PEO was stirred magnetically for two hours before being electrospun. The preparations of the solutions, as well as the preparation of the blend solution and electrospinning, were run at room temperature. The flow rate of $1 \mathrm{~mL} \mathrm{~h}^{-1}$ was determined by the solution viscosity, and the distance between the needle tips to collector cylinder was $7.5 \mathrm{~cm}$ at an applied voltage of $20 \mathrm{kV}$ (Vulcani et al., 2012).

\section{Preparation of CA polymer solutions}

The polymer solutions were prepared in the presence and absence of AgNPs. The CA polymer solution was prepared by mixing $15 \%$ cellulose acetate into DMAc/ Acetone (1:2). This solution was stirred for approximately 2 hours to ensure its complete homogenization. The samples prepared in the presence of AgNPs were made by adding $5 \%$ of an aqueous solution $(\mathrm{v} / \mathrm{w})$ containing $20 \mathrm{mg} \mathrm{L}^{-1}$ of AgNPs into the CA solution.

\section{Electrospinning of CA solutions}

CA nanostructured membranes were successfully prepared by electrospinning the CA solution with and without AgNPs at room temperature $\left(25^{\circ} \mathrm{C}\right)$ and $50 \%$ humidity, using a $20 \mathrm{~mL}$ glass syringe fitted with a $4 \mathrm{~cm}$ long, $0.8 \mathrm{~mm}$ diameter metallic needle. The positive pole of a high voltage power supply (developed in our lab) 




FIGURE 1 - a) Representative scheme of electrospinning equipment showing the spiral-shaped path of a jet using a grounded rotating device as a collector; b) Photograph of electrospinning process of a CTS/PEO blend with the addition of electrolyte using a grounded metal plate as a collector.

was connected to the metallic needle of the syringe, while the ground electrode was used to ground the copper plate collector, which had dimensions of $30 \mathrm{x} 40 \mathrm{~cm}$. The feed stream was controlled by a KD Scientific pump, Model 100 (Campinas, Brazil) connected to a syringe. The distance from the needle to the collector was $10 \mathrm{~cm}$; the applied voltage was $15 \mathrm{kV}$, and the flow rate was $1 \mathrm{~mL} \mathrm{~h}^{-1}$. Nanostructured membrane samples were collected in aluminum foil used to coat the copper plate during the experiments (Nista et al., 2012).

\section{SEM analyses}

SEM measurements were carried out using a fieldemission scanning electron microscope (Zeiss Supra 55 VP) and an SEM microscope (JEOL JSM 5900 LV). The samples were analyzed after being deposited on aluminum supports and coated with evaporated carbon. Images were obtained for each sample, with different magnitudes, which were analyzed using Image Tool ${ }^{\circledR}$ software to measure the average diameter of the 50 measurements registered by each sample.

\section{Antibacterial activity}

The antimicrobial activity of nanofibers based on CA and CTS/PEO biopolymers and impregnated with AgNPs was evaluated for their effectiveness against the Grampositive bacteria Staphylococcus aureus (S. aureus) (ATCC 29213) and Propionibacterium acnes (P. acnes) (ATCC 6919), and the Gram-negative bacteria Escherichia coli (E. coli) (ATCC 25992) and Pseudomonas aeruginosa ( $P$. aeruginosa) (ATCC 17933). The microbiological analyses were performed in 24-well culture plates. The polymeric nanofibers in the absence and presence of AgNPs were deposited in the wells of a culture plate containing Nutrient Broth medium and bacterial solution at a concentration of $105 \mathrm{CFU} \mathrm{mL}-1$. A positive control was performed only with the culture medium and bacteria. The plates were incubated at $37^{\circ} \mathrm{C}$ and rotated at a rate of $60 \mathrm{rpm}$ for 24 hours. After this incubation period, plating was performed by depositing $20 \mathrm{~mL}$ of each well into Petri dishes containing Plate Count Agar (PCA) culture medium. A positive control (growth) formed by culture broth containing bacteria and a negative control (sterile sample) formed by culture broth in which no microorganisms were included for each tested bacterial stock (Ridolfi et al., 2012). Each concentration was tested in triplicate. The plates were analyzed in order to observe the inhibitory effect of bacterial growth relative to the positive control.

\section{RESULTS AND DISCUSSION}

\section{UV-Vis spectra and DLS analysis of AgNPs}

Figure 2a shows the UV-Vis spectrum of AgNPs synthesized in aqueous medium, and Figure $2 b$ shows the AgNPs incorporated in CA polymer solution.

At approximately $400 \mathrm{~nm}$, a typical band arising from the plasmon effect of AgNPs was observed (Figure 2a) (Solomon et al., 2007). The resulting yellowish organic AgNP emulsion was characterized by DLS, and Figure $2 \mathrm{c}$ shows the size distribution of the Ag particles, with an average size of approximately $20 \mathrm{~nm}$. The confirmation that the Ag nano-sized particles were preserved after their incorporation into the CA polymer solution was confirmed 

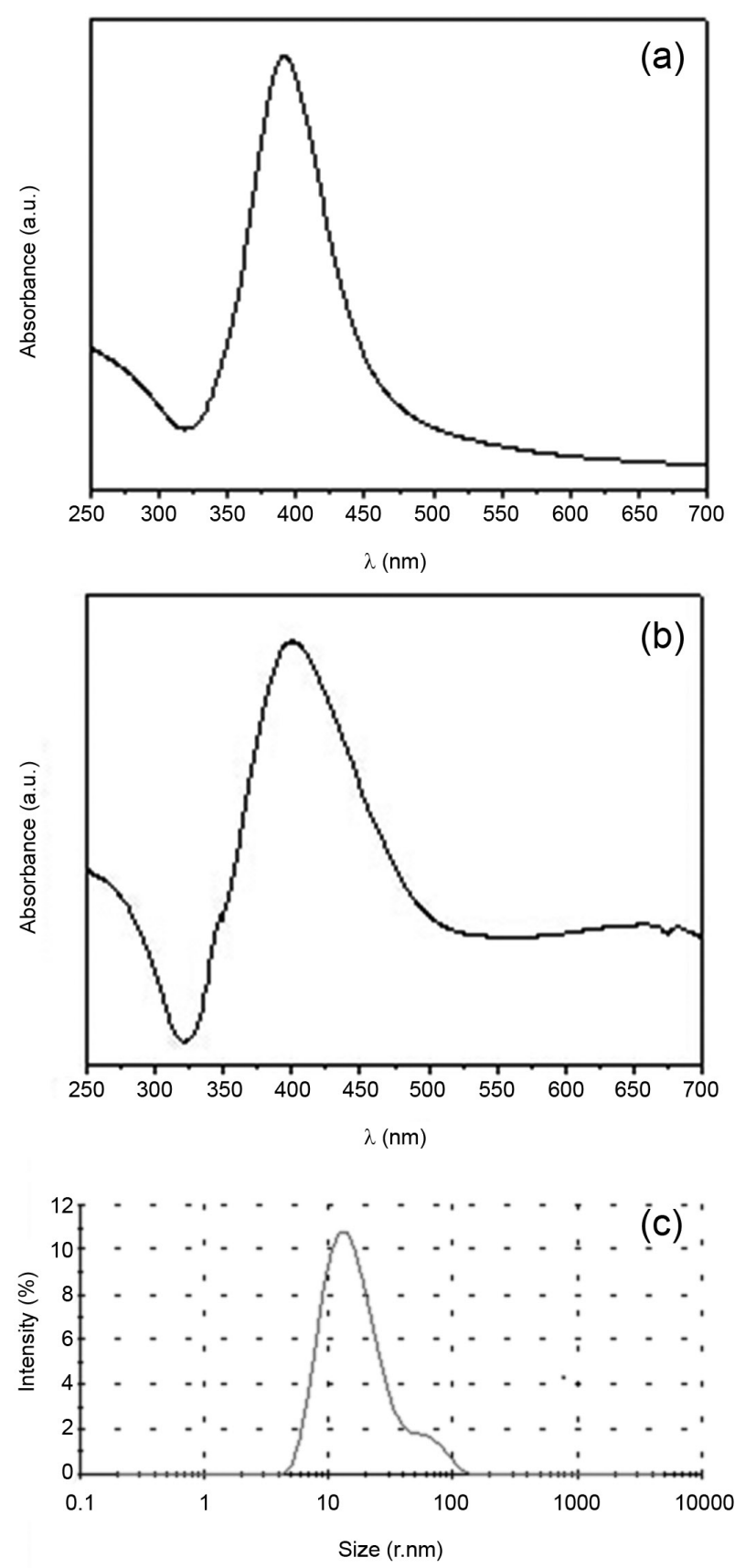

FIGURE 2 - (a) UV-Vis spectrum of AgNPs synthesized in aqueous medium (b), UV-Vis spectrum of CA/AgNPs solution and )c) DLS spectrum of AgNPs.

through the appearance of the band characteristic in $400 \mathrm{~nm}$ UV-Vis spectrums, as seen in Figure $2 b$.

\section{Nanosized Ag Particles}

The morphology and size of the nano-scale Ag particles were observed and confirmed by HR-TEM. Figure 3 shows an image of AgNPs prepared in aqueous medium.


FIGURE 3 - (a) HR-TEM of the AgNPs synthesized in aqueous medium and (b) histogram showing the particle size distribution.

Analysis of the images obtained by HR-TEM confirmed the spherical shape tendency of the AgNPs and revealed a monomodal particle size distribution with an average diameter of $20 \mathrm{~nm}$, estimated by measuring the diameter of 100 randomly selected particles in enlarged TEM images. The histogram in Figure $3 b$ shows the particle size distribution fitted by one Gaussian curve. In addition, an average size for these AgNPs can be seen, corroborating the results observed for the DLS in Figure 2c.

\section{Nanostructured membranes of CA and CTS/PEO blends in the absence and presence of AgNPs by electrospinning}

As mentioned previously, CA nanofiber membranes and CTS/PEO blends were both prepared in the absence 
and presence of AgNPs synthesized in an aqueous media and incorporated into biopolymers by in situ techniques described above. This method consists of adding the AgNPs colloidal suspension to each one of the polymeric solutions, as CA and CTS/PEO. Figure 4 shows the CTS/ PEO images obtained by SEM and Figure 5, by FEG, of CTS/PEO and CA, respectively, with AgNPs.



FIGURE 4 - Micrographs of SEM of CTS/PEO nanofibers in the presence of AgNPs.

Nanofiber membranes were well formed, without beading, as shown in Figure 5 for both electrospun biopolymers. The average diameters of the CA and CTS/ PEO nanofibers electrospun with AgNPs were both in the nanometer range. As seen, the diameter of the fibers obtained in electrospinning experiments increased a little due to the amount of AgNPs added, but this did not interfere with the nanofiber membrane formation process. It was observed that the conductivities of the CA solutions increased in the presence of AgNPs, jumping from 8 to $12.5 \mu \mathrm{S} \mathrm{cm}-1$, without and with AgNPs, respectively. Consequently, the potential applied during the electrospinning process needed to be decreased by 5 $\mathrm{kV}$ in order to form good nanofiber membranes.

Figure 6 shows FEG images of nanofibers formed in the presence of AgNPs. With the aid of high-resolution FEG and higher magnification, AgNPs can be visualized as many white spots dispersed inside nanofibers of CA and CTS/PEO formed in the presence of AgNPs, shown in Figure $6 \mathrm{~b}$ and Figure $6 \mathrm{c}$, respectively. This phenomenon is not observed for those samples (nanofibers) made without Ag NPs (Figure 6a).

The observed morphological aspects of the AgNPs (preferably spherical, see Figure 3) and the particle sizes as measured by DLS (Figure 2b) and confirmed by TEM (see Figures $6 \mathrm{c}$ and 3 ) corroborate this interpretation. Further consideration of the micrographs obtained of the
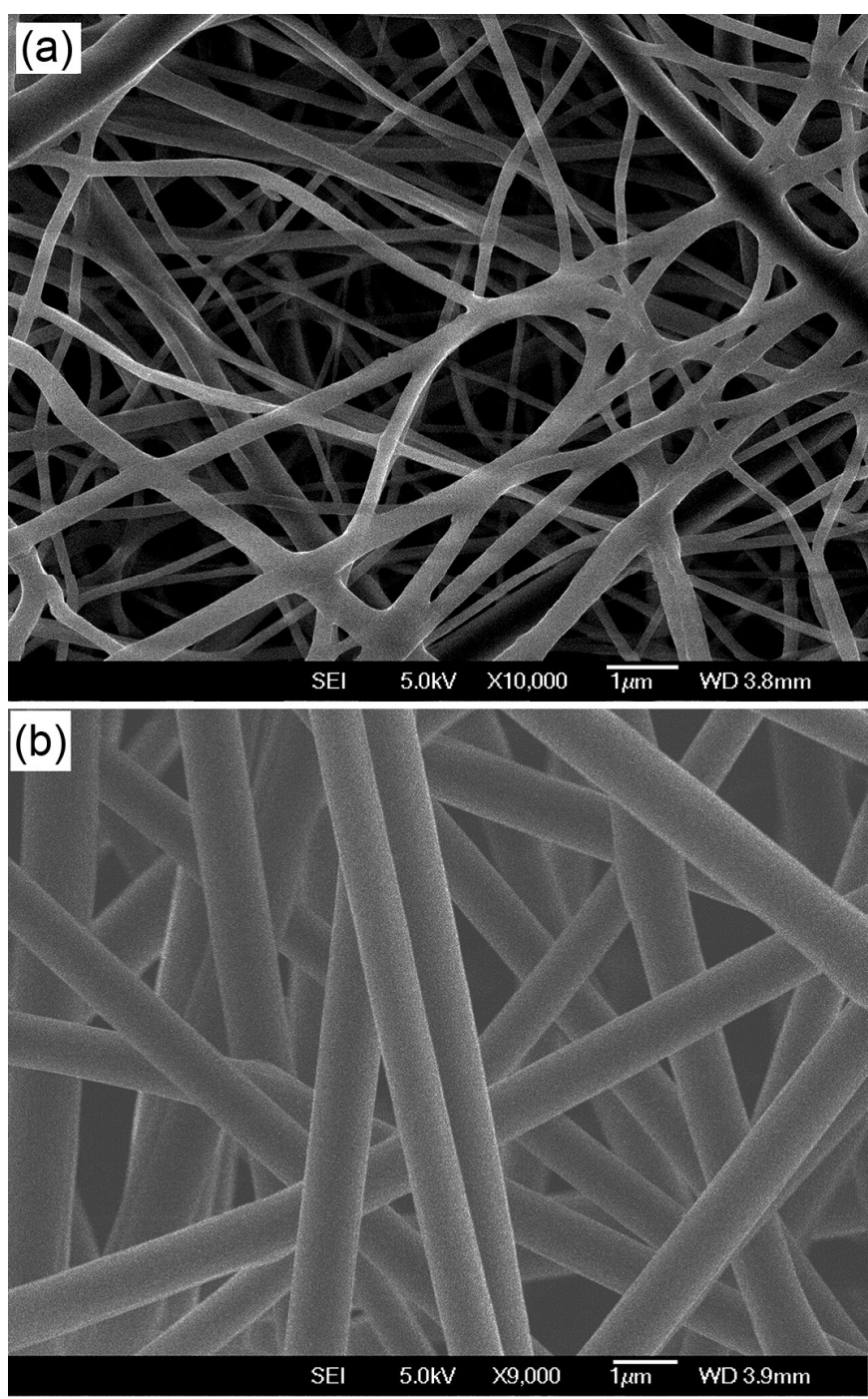

FIGURE 5 - FEG micrographs of a) bare CTS/PEO CA nanofibers and $\mathbf{b}) \mathrm{CTS} / \mathrm{PEO} \mathrm{CA}$ nanofibers in the presence of AgNPs.

CA (Figure 6a) and the CTS/PEO nanofibers by FEG in the absence of AgNPs, makes it clear that these white spots are not observed in these samples (nanofibers without AgNPs, Figure 6a). Therefore, in comparing images made simultaneously on the same equipment and after the same nanofiber surface treatment, but only differing in whether they were made with or without AgNPs, it is possible that the white dots observed in the nanofibers that formed in the presence of Ag are indeed on the scale of NPs.

\section{Antibacterial activity}

The antibacterial activity of nanostructured biopolymer membranes made of CA and the CTS/ PEO nanocomposites with AgNPs and prepared using the in situ method, were tested against Gram-positive 

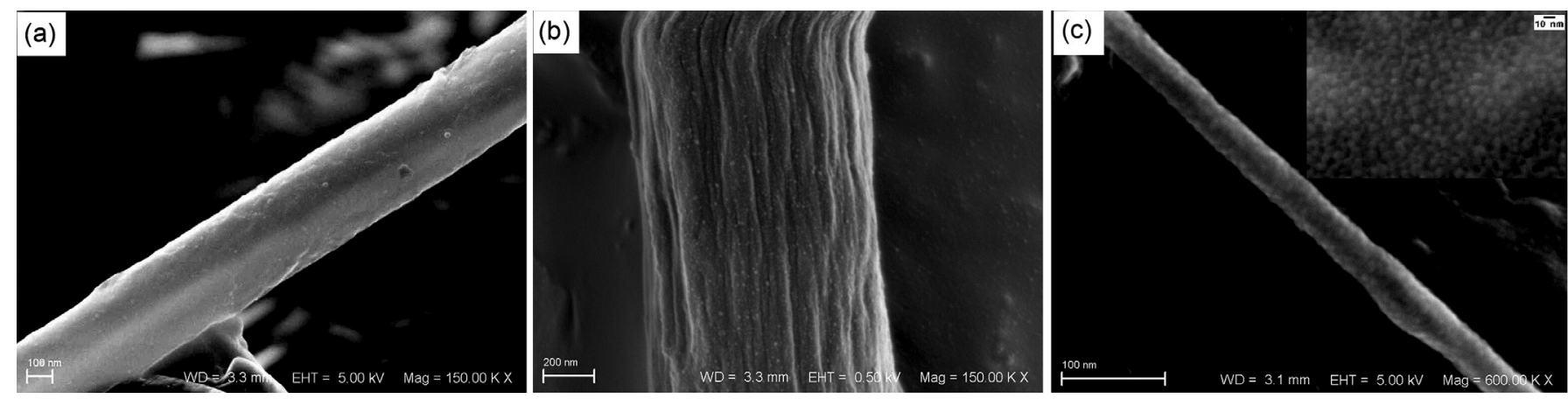

FIGURE 6 - Micrographs of FEG of CA nanofibers made in the a) absence of AgNPs and the b) presence of AgNPs, and c) CTS/ PEO electrospun membranes made with AgNPs. The inset at the top right corner shows AgNPs powder.

\section{S. aureus (ATCC 29213) and P. acnes (ATCC 6919)} microorganisms, as well as the Gram-negative E. coli (ATCC 25992) and P. aeruginosa (ATCC 17933). Table I illustrates the results obtained.

The microbiological analyses were performed on solid medium (plate method), so that the CA and CTS/ PEO nanofibers can be observed as in Figure 7. In the case of the CA nanofibers, it was observed that in the presence of AgNPs (black dotted line) there was growth inhibition only for E. coli, a Gram-negative bacterium (Figure 7a). The same methodology was performed with nanostructured electrospun membranes of CTS/PEO. In this case, bacterial growth inhibition was observed for P. acnes, a Gram-positive bacterium (Figure 7d, white dotted line). These results indicate that the nanofibers in the presence of Ag NPs are leaching onto some microorganism.

The results observed in the incubated Petri dishes corroborate the visual observations of the culture plates in relation to turbidity, which indicates bacterial growth. These results showed that both microbiological tests (carried out in triplicate) were reproducible and comparable.

Studies have shown that light, temperature and the presence of oxygen are important factors in redox behavior and therefore in the bactericidal effect of $\mathrm{Ag}$ in a material. In this way, it was demonstrated that $\mathrm{Ag}$ is reduced in the presence of light (Geranio, Heuberger, Nowack, 2009) and that $\mathrm{Ag} 0$ dissolution is accelerated when the temperature increases (Kittler et al., 2010); some exchanged Ag zeolites have a bactericidal effect only under aerobic conditions, while others have shown low antimicrobial effect under anaerobic conditions. Therefore, the physical conditions of the medium are important and should be considered in studies related to the bactericidal effect of Ag. However, when investigating the antibacterial effect of AgNPs, other aspects must be considered, including the crystallinity of the NPs, their geometry, size, surface area, surface oxidation, agglomerative state in the biological medium,
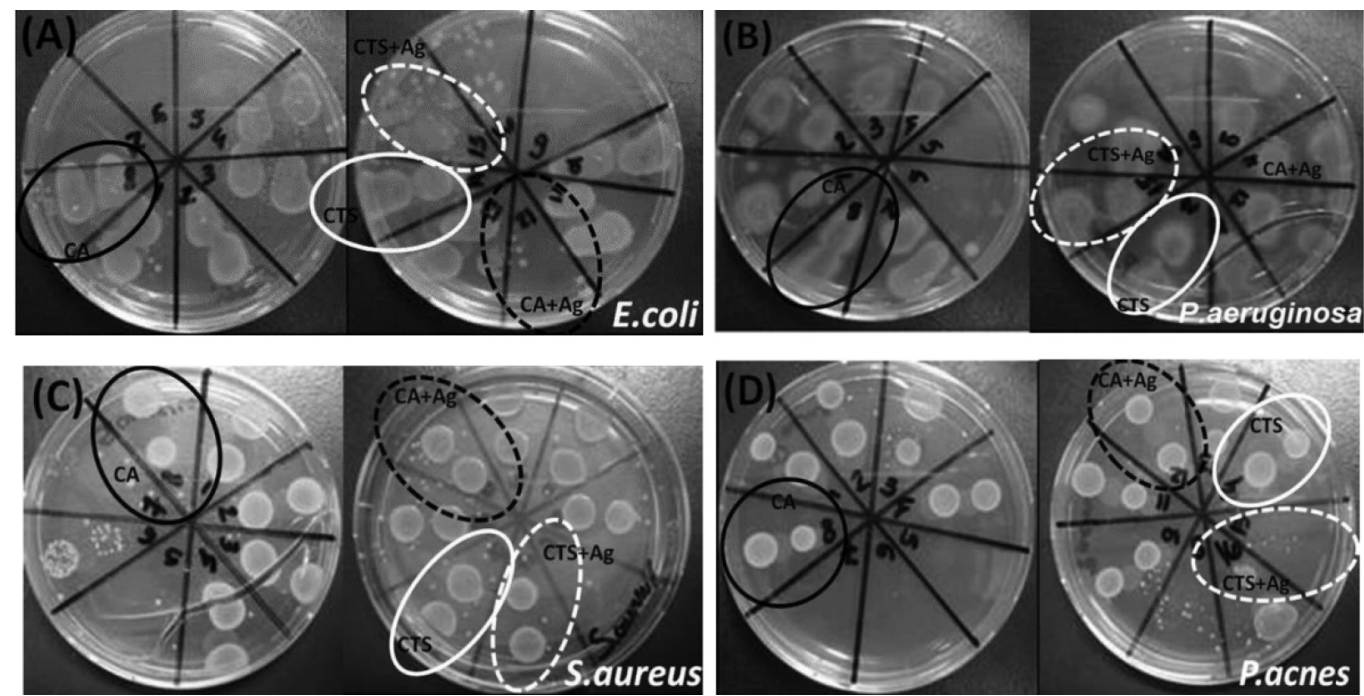

FIGURE 7 - Image of solid medium (plate method) after 24 hours of bacterial growth of (a) E. coli, (b) P. aeruginosa, (c) S. aureus, (d) $P$. acnes in CA (black) and CTS/PEO (white) nanofibers in the absence (solid line) and presence of AgNPs (dotted line). 
TABLE I - Analysis of bacterial growth after a $24 \mathrm{~h}$ incubation period for microorganisms tested in both plate medium and test tubes

\begin{tabular}{llcccc}
\hline \multirow{2}{*}{ Microorganisms tested } & \multicolumn{4}{c}{ Analysis of bacterial growth after 24h incubation } \\
\cline { 2 - 5 } & & CA nanofibers & CA + AgNPs & CTS/PEO nanofibers & CTS/PEO + AgNPS \\
\hline \multirow{2}{*}{ Gram negative } & E. coli & + & - & + & + \\
& P. aeruginosa & + & + & + & + \\
\hline \multirow{2}{*}{ Gram positive } & S. aureus & + & + & + & + \\
& P. acnes & + & + & + & - \\
\hline
\end{tabular}

Legend: (+) growth and (-) no bacterial growth

the surface charge of the NPs, the functional groups present on the surface, and many others. Pal et al. (2007) showed that the triangular shape of AgNPs exhibited higher biocide action on the bacterium $E$. coli when compared to spherical or cylindrical NPs, and even to $\mathrm{AgNO}_{3}$, making it clear that different geometrical shapes of NPs have different reactivities and potencies.

A relevant factor in the evaluation of biocide action on different materials is their behavior against the bactericidal dose-dependent effect on the strains. Due to the complexity involved in determining the real bioavailability of Ag ions, values of minimum inhibitory concentration (MIC) to approximately 100 strains of $S$. aureus were reported, with a range between $8-80 \mathrm{mg} \mathrm{L}^{-1}$ when using $\mathrm{AgNO}_{3}$ (Chopra, 2007). Similarly, MIC values for Ag studied in approximately 100 strains of $P$. aeruginosa showed a range of 8 to $70 \mathrm{mg} \mathrm{L}^{-1}$. These studies showed that some strains are resistant to $\mathrm{Ag}$, and, in fact, the resistant mechanism of bacterial strains was isolated more than 70 years ago, and their $\mathrm{Ag}$ resistance mechanism has been investigated (Pal, Tak, Song, 2007; Yudkin, 1937).

A very important aspect of Ag action on bacterial cells, which must be considered when discussing the inhibitory effect of Ag tested on different types of microorganisms, is the classification of the bacterium. Bacteria are commonly classified into Gram positive and Gram negative, depending on their cell walls. Grampositive bacteria have an extra thick peptidoglycan layer on the outer surface, while Gram-negative bacteria have an outer membrane behind which a thin peptidoglycan layer exists. This drastic difference in the nature of the cell boundaries is a great challenge for having a general antibacterial material against the bacteria (Gangadharan et al., 2010).

Therefore, the biopolymeric nanofibers prepared by incorporating AgNPs can provide antiseptic properties required of new materials that could be used to great benefit in medical devices.

\section{CONCLUSION}

Microbial experiments suggested that CA electrospun nanofibers containing AgNPs showed a much better antimicrobial effect on the bacterium E. coli, a common pathogen affecting humans and other animals that is an important bacterium associated with hospital infections. In the case of the electrospun nanofiber membrane made of CTS/PEO impregnated with AgNPs, the growth inhibition effect was observed for Gram-positive bacteria, such as $P$. acnes, indicating that these membranes present bactericidal action through both contact and leaching action. The results observed in the incubated Petri plates corroborate the visual observation performed on culture plates in relation to turbidity. Thus, it is supposed that the electrospun CTS/PEO and CA nanofibers, both biopolymers and both made in the presence of AgNPs, with the demonstrated and strong antimicrobial activity could be used in various biomedical fields such as wound dressings, mesh grafts in burns, and tissue scaffolds. An assessment of the antimicrobial activity of the final products and other issues related to the understanding of this new material is under way in the laboratories of the authors.

\section{ACKNOWLEDGEMENTS}

The authors thank National Council for Scientific and Technological Development (CNPq), Coordination for the Improvement of Higher Education Personnel (CAPES) and São Paulo Research Foundation (FAPESP) for the financial support and scholarship. The authors would like to thank the Brazilian Nanotechnology National Laboratory/Center for Research in Energy and Materials (LNNano/CNPEM) for technical support during electron microscopy work. We also acknowlwedge Brazilian Network on Nanotoxicology (MCTI/CNPq) and NanoBioss (MCTI) for support. We would also like to thank Nature Publishing Group for the certification of this manuscript review into an English Certified Edition. 


\section{REFERENCES}

ABDELGAWADA, A.M.; HUDSONA, S.M.; ROJAS, O.J. Antimicrobial wound dressing nanofiber mats from multicomponente (chitosan/silver-NPs/polyvinyl alcohol) systems. Carbohydr. Polym., v.100, p.166-178, 2014.

ABOU-ZEIDA, N.Y.; WALYA, A.I.; KANDILEB, N.G.; RUSHDYC, A.A.; EL-SHEIKHA, M.A.; IBRAHIM, H.M. Preparation, characterization and antibacterial properties of cyanoethylchitosan/cellulose acetate polymer blended films. Carbohydr. Polym., v.84, n.1, p.223-230, 2011.

ALEXEEV, V.L.; KELBERG, E.A.; EVMENENKO, G.A.; BRONNIKOV, S.V. Improvement of the mechanical properties of chitosan films by the addition of poly(ethylene oxide). Polym. Eng. Sci., v.40, n.5, p.1211-1215, 2000.

BIZARRIA, M.T.; DAVILA, M.A.; MEI, L.H.I. Nonwoven nanofiber chitosan/PEO membranes obtained by electrospinning. Braz. J. Chem. Eng., v.31, n.1, p.57-68, 2014.

CHALOUPKA, K.; MALAM, Y.; SEIFALIAN, A.M. Nanosilver as a new generation of nanoproduct in biomedical applications. Trends Biotechnol., v.28, n.11, p.580-588, 2010.

CHEN, X.; PARKER, S.G.; ZOU, G.; SU, W.; ZHANG, Q. $\beta$-Cyclodextrin functionalized silver nanoparticles for the naked eye detection of aromatic isomers. ACS Nano., v.4, n.11, p.6387-6394, 2010.

CHOPRA I. The increasing use of silver-based products as antimicrobial agents: a useful development or a cause for concern. J. Antimicrob. Chemother., v.59, n.4, p.587-590, 2007.

DALLAS, P.; SHARMA, V.K.; ZBORIL, R. Silver polymeric nanocomposites as advanced antimicrobial agents: Classification, synthetic paths, applications, and perspectives. Adv. Colloid Interface Sci., v.166, n.1-2, p.119-135, 2011.

DUTRA, R.L.; SEGALA, K.; DE OLIVEIRA, E.M.N.; DE SOUZA, E.P.; ROSSI, L.M.; MATOS, J.R.; NODA, L.K.; PAULA, M.M.S.; FRANCO, C.V. Preparation and characterization of the novels terpolymers of poly-\{trans[RuCl2(vpy)4]-styrene-divinylbenzene $\}$ and styrenedivinylbenzene-vinylpiridine impregnated with silver nanoparticles. Polym. Bull., v.60, p.809-819, 2008.
ELliSON, J.; WYKOFF, G.; PAUL, A.; MOHSENI, R.; VASILIEV, A. Efficient dispersion of coated silver nanoparticles in the polymer matrix. Colloids Surf., A: Physicochem. Eng. Aspects, v.447, p.67-70, 2014.

FERJANI, E.; LAJIM, R.H.; DERATANIB, A.; ROUDESLIB, M.S. Bulk and surface modification of cellulose diacetate based RO/NF membranes by polymethylhydrosiloxane. Preparation and characterization. Desalination, v.146, n.13, p.325-330, 2002.

G ANGADHARAN, D.; HAR S HVARDAN, K.; GNANASEKAR, G.; DIXIT, D.; POPAT, K.M.; ANAND, P.S. Polymeric microspheres containing silver nanoparticles as a bactericidal agent for water disinfection. Water Res., v.44, n.18, p.5481-5487, 2010.

GERANIO, L.; HEUBERGER, M.; NOWACK, B. The behavior of silver nanotextiles during washing. Environ. Sci. Technol., v.43, p.8113-8118, 2009.

GUO, L.; YUAN, W.; LU, Z.; LI, C.M. Polymer/nanosilver composite coatings for antibacterial applications. Colloids and Surf. A: Physicochem. Eng. Aspects, v.439, p.69-83, 2013.

HAN, B.; ZHANG, D.; SHAO, Z.; KONG, L.; SHAOYI, Lv. Preparation and characterization of cellulose acetate/ carboxymethyl cellulose acetate blend ultrafiltration membranes. Desalination, v.311, p.80-89, 2013.

JANA, N. R.; GEARHEARTA, L.; MURPHY, C. J. Wet chemical synthesis of silver nanorods and nanowiresof controllable aspect ratio. Chem. Commun., p.617-618, 2001.

KANMANI, P.; RHIM, J. Physicochemical properties of gelatin/ silver nanoparticle antimicrobial composite films. Food Chem., v.148, p.162-169, 2014.

KHAN, N. Applications of electrospun nanofibers in the biomedical field: a review. Stud. Undergrad. Res. Guelph, v.5, n.2, p.63-73, 2012.

KITTLER, S.; GREULICH, C.; DIENDORF, J.; KOELLER, M.; EPPLE, M. Toxicity of silver nanoparticles increases during storage because of slow dissolution under release of silver ions. Chem. Mater., v.22, n.16, p.4548-4554, 2010. 
KLEINUBING, S.A.; SERAPHIM, D.C.; VIEIRA, M.G.A.; CANEVESI, R.L.S.; SILVA, E.A.; CÉSAR, C.L.; MEI, L.H.I. Gastro-resistant controlled release of OTC encapsulated in alginate/chitosan matrix coated with acrylEZE MP in fluidized bed. J. Appl. Polym. Sci., v.131, n.12, p.1-9, 2014.

KVITEK, L.; PANACEK, A.; SOUKOPOVA, J.; KOLAR, M.; VECEROVA, R.; PRUCEK, R.; HOLECOVA, M.; ZBORIL, R.J. Effect of surfactants and polymers on stability and antibacterial activity of silver nanoparticles (NPs). J. Phys. Chem. C, v.112, n.15, p.5825-5834, 2008.

LIU, C.J.; BURGHAUS, U.; BESENBACHER, F.; WANG, Z.L. Preparation and characterization of nanomaterials for sustainable energy production. ACS Nano, v.4, n.10, p.5517-5526, 2010.

MADHUMATHI, K.; SUDHEESH, KUMAR, P.T.; ABHILASH, S.; SREEJA, V.; TAMURA, H.; MANZOOR, K.; NAIR, S.V.; JAYAKUMAR, R. Development of novel chitin/nanosilver composite scaffolds for wound dressing applications. J. Mater. Sci: Mater. Med., v.21, n.2, p.807813,2010

MURPHY, C. J.; JANA, N. R. Controlling the Aspect Ratio of Inorganic Nanorods and Nanowires. Adv. Mater., v.14, n.1, p.80-82, 2002.

NISTA, S.V.G.; BETTINI, J.; MEI, L.H.I. Coaxial nanofibers of chitosan-alginate-PEO polycomplex obtained by electrospinning. Carbohydr. Polym., v.127, p.222-228, 2015.

NISTA, S.V.G.; AKIRA, M.D.; MARTINEZ, E.F; SILVA, A.S.F., MEI, L.H.I. Nanostructured membranes based on cellulose acetate obtained by electrospinning. Part II. Controlled release profile and microbiological behavior. $J$. Appl. Polym. Sci., v.130, n.4, p.2772-2779, 2013.

NISTA, S.V.G.; PERES, L.; D’Á VILA, M.A.; SCHMIDT, F.L.; MEI, L.H.I. Nanostructured membranes based on cellulose acetate obtained by electrospinning, part 1: Study of the best solvents and conditions by design of experiments. J. Appl. Polym. Sci., v.126, n.S1, p.E70-E78, 2012.

OKAMOTO, M.; JOHN, B. Synthetic biopolymer nanocomposites for tissue engineering Scaffolds. Prog. Polym. Sci., v.38, n.10-11, p.1487-1503, 2013.
PADIL, V.V.T.; NGUYEN, N.H.A.; ŠEVCR, A.; HERNÍK, M. Fabrication, Characterization, and Antibacterial Properties of Electrospun Membrane Composed of Gum Karaya, Polyvinyl Alcohol, and Silver Nanoparticles. J. Nanomater. v.2015, ID 750726, 2015.

PAL, S.; TAK, Y.K.; SONG, J.M. Does the antibacterial activity of silver nanoparticles depend on the shape of the nanoparticle? A study of the Gram-negative bacterium Escherichia coli. Appl. Environ. Microbiol., v.73, n.6, p.1712-1720, 2007.

PANACEK, A.; KVITEK, L.; PRUCEK, R.; KOLAR, M.; VECEROVA, R.; PIZUROVA, N.; SHARMA, V.K.; NEVECNA, T.; ZBORIL, R. Silver colloid nanoparticles: synthesis, characterization, and their antibacterial activity. J. Phys. Chem. B, v.110, n.33, p.16248-16253, 2006.

PRABHU, S.; POULOSE, E.K. Silver nanoparticles: mechanism of antimicrobial action, synthesis, medical applications, and toxicity effects. Int. Nano. Lett., v.2, p.3-10, 2012.

PREMA, P.; RAJU, R. Fabrication and characterization of silver nanoparticle and its potential antibacterial activity. Biotechnol. Bioproc. Eng., v.14, p.842-847, 2009.

RAI, M.; YADAV, A.; GADE, A. Silver nanoparticles as a new generation of antimicrobials. Biotechnol. Adv, v.27, p.7683, 2009.

RHIM, J.W.; WANG, L.F.; HONG, S.I. Preparation and characterization of agar/silver nanoparticles composite films with antimicrobial activity. Food Hydrocol., v.33, n.2, p.327-335, 2013.

RIDOLFI, D.M.; MARCATO, P.D.; JUSTO, G.Z.; CORDI, L.; MACHADO, D.; DURÁN, N. Chitosan-solid lipid nanoparticles as carriers for topical delivery of tretinoin. Colloids Surf. B Bioint., v.93, p.36-40, 2012.

SEVERIN, N.; KIRSTEIN, S.; SOKOLOV, I.M.; RABE, J.P. Rapid trench channeling of graphenes with catalytic silver nanoparticles. Nano Lett., v.9, n.1, p.457-461, 2009.

SIGNORI, A.M.; SANTOS, K.O.; EISING,R.; ALBUQUERQUE, B.L.; GIACOMELLI, F.C.; DOMINGOS, J.B. Formation of catalytic silver nanoparticles supported on branched polyethyleneimine derivatives. Langmuir, v.26, n.22, p.17772-17779, 2010. 
SOLOMON, S.D.; BAHADORY, M.; JEYARAJASINGAM, A.V.; RUTKOWSKY, S.; BORITZ, C. MULFINGER, L. Synthesis and study of silver nanoparticles. J. Chem. Educ., v.84, n.2, p.322-325, 2007.

SOYEKWO, F.; ZHANG, Q.G.; DENG, C.; GONG; ZHU, A.M.; LIU, Q.L. Highly permeable cellulose acetate nanofibrous composite membranes by freeze-extraction. $J$. Membr. Sci, v.454, p.339-345, 2014.

TRICOLI, A.; PRATSINIS, S.E. Dispersed nanoelectrode devices. Nat. Nanotechnol., v.5, p.54-60, 2009.

VULCANI, V.A.S.; BIZARRIA, M.T.M.; D’ÁVILA, M.A.; MEI, L.H.I.; BERNALD, C.; PERUSSI, J.R. Cytotoxicity tests for nanostructured chitosan/PEO membranes using the agar diffusion method. Mat. Res., v.15, p.213-217, 2012.
YUDKIN J. Effect of silver ions on enzymes of Bacterium coli. Enzymologia, v.2, p.161-70, 1937.

ZENG, Q.; JIANG, X.; YU, A.; LU, G. Growth mechanisms of silver nanoparticles: a molecular dynamics study. Nanotechnology, v.18, n.3, p.035708, 2007.

ZIVANOVIC, S.; LI, J.; DAVIDSON, P.M.; KIT, K. Physical, mechanical and antibacterial properties of chitosan/PEO blend films. Biomacromolecules, v.8, n.5, p.1505-10, 2007.

Received for publication on $25^{\text {th }}$ November 2014 Accepted for publication on $17^{\text {th }}$ September 2015 
